\title{
LITERATURE REVIEW \\ Empirical attributes and limitations of methodologies for predicting the degradability of ruminal protein
}

\author{
Alejandro Velásquez ${ }^{1,2}$, Jordana Rivero ${ }^{1,2}$, and Pierre-Guy Marnet ${ }^{3}$ \\ ${ }^{1}$ Escuela de Agronomía, Facultad de Recursos Naturales. ${ }^{2}$ Núcleo de Investigación en Producción \\ Alimentaria. Universidad Católica de Temuco. Manuel Montt 56, Temuco, Chile. \\ ${ }^{3}$ Département Productions Animales, Agroalimentaire, Nutrition (P3AN). UMR INRA-Agrocampus Ouest \\ 1348, Rennes, France.
}

\begin{abstract}
A. Velásquez, J. Rivero, and P.-G. Marnet. 2016. Empirical attributes and limitations of methodologies for predicting the degradability of ruminal protein. Cien. Inv. Agr. 43(2):171-189. The object of the present review is to analyze the methodologies that are commonly used to estimate protein degradability in the rumen, focusing on their attributes and limitations to offer suggestions for improving their use. This information is essential for selecting food types when formulating feed diets. A reliable prediction of the digestibility of ruminal proteins is basic information necessary for optimizing the use of nitrogenous sources because digestibility can translate, on the one hand, into higher yields of milk, milk protein, meat or wool and, on the other hand, into lower excretion of nitrogenous compounds into the environment; it also has an impact on animal health and welfare. Traditionally, the digestibility of feed proteins in the rumen has been predicted by in vivo, in situ and in vitro methods, but other techniques based on infrared spectroscopy have been developed, notably the NIRS and FTIR methods. All of these techniques present limitations, such as a disturbance factor or a source of error, that may result in inaccurate predictions. The in situ and in vitro methods, which use enzyme extracts of ruminal origin, and FTIR probably have the greatest advantages, but they need to be perfected through further research.
\end{abstract}

Key words: Ruminal protein degradability, methodologies, limitations.

\section{Introduction}

The efficiency of nitrogen use in ruminants is primarily affected by the degradability dynamic of the nitrogenous compounds in the ruminal ecosystem, the availability of fermentable energy in the rumen and the subsequent nitrogenous metabolism in the

Received January 29, 2016. Accepted July 18, 2016. Corresponding author: avelasquez@uct.cl animal. The prediction of protein degradability in the rumen is basic information that is necessary to optimize the food resources used for ruminant nutrition (e.g., synchronization of the availability of $\mathrm{N}$ and energy in the rumen), and an accurate prediction also assists in ensuring animal welfare and reducing the environmental impact generated by the excretion of nitrogenous compounds into the environment (Van Duinkerken et al., 2005; Kaswari et al., 2007; Riasi et al., 2008; Rezaei et 
al., 2015). Feed protein degradation in the rumen is highly unpredictable because, on the one hand, feeds contain different nitrogenous compounds with widely varying molecular compositions and spatial structures at the histological and cell levels; on the other hand, they are subjected to an enzymatic digestion environment that is diverse and difficult to predetermine (Van Soest, 1994; Stern et al., 1997; Encinias et al., 2005; Razzaghi et al., 2016). Skewed information on the actual degradability of proteins in the rumen can lead to errors in ruminant feeding. Underestimating the real nitrogen contribution of the feed to the ruminal ecosystem, combined with a low availability of energy for microorganisms, would increase the amount of $\mathrm{N}$ excreted in urine and feces. Under such conditions, the ruminal epithelium would generate $\mathrm{N}$ homeostasis between the ruminal medium and the plasma level by absorbing the excess $\mathrm{N}$ (principally in the form of ammonium) not fixed by the microorganisms to maintain the nitrogen equilibrium in the ruminal medium. Additionally, this absorption of ammonium would have metabolic consequences for the kidneys, liver and mammary glands (Kornegay, 1996; Van Duinkerken et al., 2005; Castro-Montoya et al., 2016). It is also important to have as accurate information as possible on the degradability of polypeptides in the rumen to establish balanced diets, thus optimizing the efficient use of $\mathrm{N}$. Thus, the accuracy and representativeness of the methods used for predicting protein degradability in the rumen play a fundamental role in optimizing the use of nitrogenous resources through the formulation of diets for productive ruminants (Givens et al., 2000; Benninghoff et al., 2015). The methodologies traditionally used for predicting the dynamics of proteolysis in the rumen have undergone little technical modification; they have contributed to animal nutrition without any major examination or criticism and have been accepted as unquestionable references for the quality of the information provided. However, to a greater or lesser degree, there are a series of limitations or disturbance factors inherent to the technical aspects of these methodologies that could result in skewed estimates of the real digestibility of the proteins in the ruminal ecosystem (Broderick, 1987; Russell et al., 1992; Sniffen et al., 1992; Yan and Agnew, 2004; Encinias et al., 2005; Zagorakis et al., 2015). These limitations can lead, among other things, to the inefficient use of protein resources during ruminant feeding and economic losses for the producer. Therefore, there is a need to perfect these methodologies, or find new ones, to improve the prediction of the kinetics of feed proteolysis in the rumen. The object of the present study was to analyze the predictive effectiveness of the commonly used methodologies to estimate the degradability of proteins in the rumen to facilitate their improvement and establish guidelines for the future creation or investigation of alternative methods.

\section{Complexity of proteolysis in the ruminal ecosystem}

The kinetics of protein degradation in the ruminal ecosystem are affected by complex interactions between biotic and abiotic components resulting in biological conditions that are difficult to simulate with great accuracy or precision; there is great variability among observations made using in vitro, in situ or in vivo methods (Stern et al., 1994; Broderick et al., 2004; Cone et al., 2004; Habib et al., 2013; Hao et al., 2016). The most important biological components are related to the biodiversity and ecological behavior of the microorganisms in the rumen, principally their bioenergetic, enzymatic and hydrolytic processes and they synthesis of microbial proteins. Basically, these components involve the fermentation of carbohydrates (structural and non-structural), lipolysis-biohydrogenation, proteolytic activity and $\mathrm{N}$ capture, which are normally associated with reproduction and cell growth. They also constitute an important biological element that influences the effectiveness of the adherence and colonization mechanisms of the particles digested by the microorganisms. 
Nitrogen recycling in the rumen and at intermediate levels in ruminants, the kinetics of particle escape (ruminal retention time) and feed consumption and feeding frequency are incidental factors affecting protein degradation dynamics in the rumen (Sniffen et al., 1992; Broderick et al, 2004; Costa et al., 2016). During the digestion of organic material in the rumen, the hydrolytic interaction of microbial consortia through the synthesis and excretion of hydrolytic enzymes, enzyme-substrate affinity and hydrolysis kinetics are of great importance in determining the magnitude of protein digestion. There is an ecological phenomenon known as syntrophy that accounts for the simultaneous proteolytic, amylolytic or fibrolytic enzyme activity of some microorganisms, such as the bacteria Butyrivibrio fibrisolvens and Prevotella ruminicola, whose digestive activity is based on the degradation of both proteins and cellulose. Likewise, Succinimonas amylolytica, Bacteroides amylophilus, Selenomonas ruminantium and Streptococcus bovis simultaneously present proteolytic and amylolytic activity (Van Soest, 1994; Kornegay, 1996). During the digestion of structural (cell wall) and non-structural carbohydrates (e.g., starch), various species of microorganism make use of this phenomenon to break into the feed cells and digest both the free and compartmentalized cytoplasm proteins in cell organelles. They can also hydrolyze the polypeptides located among the lignocellulosic and hemicellulosic molecular complexes of the cell walls. The action of bacterial amylases and protozoa permit access to proteins, which are physically and chemically compromised with starchy structures (Chamberlain and Choung, 1995; Bull, 2001; Hristov et al., 2008; Zhao et al., 2016).

The characteristics of polypeptides also determine their degree of susceptibility to the action of proteases. The solubility and the structural properties of proteins, such as the presence and number of sulfur bridges, the ionic charges at the surface and the degree of folding and hydrophobicity, are factors that determine the magnitude and effectiveness of the proteolytic attack by the ruminal microorganisms (Peltekova and Broderick, 1996). Proteolysis occurs in the form of nucleophile attacks on the peptide bonds, which may be endoproteolytic or exoproteolytic, by proteases, and the process normally occurs on the outside of cells that are intimately associated with the bacterial wall (e.g., adsorption of the proteins in cellulosomes) or occurs freely in other situations, with proteases being excreted into the ruminal medium. Nevertheless, bacteria exist which, depending on their species and strain, the trophic conditions of the moment, their molecular weight and the biochemical characteristics of the polypeptides to be digested, cause intracellular hydrolysis of the polypeptides (Asplund, 1994; Swanepoel et al., 2016). The protozoa typically swallow proteins, microparticles and microorganisms whole (e.g., bacteria, protozoa, and fungi), implying that, in most cases, protein digestion by these microorganisms is intracellular.

The above information suggests that the greatest concentration of proteases may be found in the periplasm of the bacteria and on the surface of their cell walls, on the cytoplasm of some of the bacteria and in the protoplasm of most of the protozoa as well as in the most intimate microhabitats around and within the feed particles to be digested. These findings are particularly important for the in vitro methods that are based on the extraction of ruminal enzymes to predict the degradability of proteins in the rumen (Velásquez and Pichard, 2010a).

Following protein degradation, the generated amino acids may follow different metabolic paths, which will depend in part on the concentrations of ammonium, amino acids, peptides, oligopeptides, polypeptides, carbonic skeletons and fermentable energy in the ruminal medium. These amino acids can be deaminated, producing ammonium and isoacids, or used directly in the synthesis of microbial proteins. For example, the deamination of valine, leucine and isoleucine produces the final molecules of isobutyrate, isovalerate and 
2-methylbutyrate, respectively (as well as carbon dioxide and ammonium). From a methodological point of view, the importance of these phenomena for predicting protein degradability is that these acids and other metabolites can form substrates that promote microbial growth and reproduction, principally for many cellulolytic bacteria and other microorganisms that use these fatty acids as sources of energy and/or carbon chains. Normally, these isoacids, in conjunction with ammonium fixation, allow de novo synthesis of microbial amino acids (Ørskov, 1992; Van Soest, 1994; Chamberlain and Choung, 1995; Bull, 2001; Swanepoel et al., 2016), and the magnitude of the synthesis is mainly regulated by the activity of the enzymes glutamine synthetase, NADP-glutamate dehydrogenase and NAD-alanine dehydrogenase, whose $K_{m}$ values for ammonium fixation are $1.8,1.8$ to 3.1 , and $70 \mathrm{mM}$ of ammonium, respectively (Asplund, 1994). It should be noted that the degree of enzyme substrate affinity $\left(K_{m}\right)$ will determine, in some way, the activity levels of these enzymes as a function of the intracellular nitrogen concentration of the microorganisms and the $\mathrm{N}$ content in the ruminal medium. The variability in the activity of these enzymes will affect the availability and diversity of synthesized amino acids and their subsequent involvement in proteic anabolism and later effects on the levels of microbial protease excretion (Chamberlain and Choung, 1995; Bull, 2001).

All of these phenomena, which are in some way related to the enzyme activity in the rumen, must be empirically considered in any biological method that attempts to predict protein degradability in the rumen. Microbial biodiversity, including the resulting variability in the enzyme spectrum in the rumen, can be modified through substrateinduction, which can lead to changes in the extent and rates of ruminal protein degradation. This has been empirically demonstrated through protein digestibility assays both in situ and in vitro, so it is indeed possible to generate a change in the microbial biodiversity of the ruminal ecosystem by differentially stimulating the synthesis and specific secretion of microbial proteases and carbohydrases (Hungate, 1966; Velásquez and Pichard, 2010a). For example, it appears that a feeding plan rich in cell walls (NDF) would stimulate population (biomass-microbial) growth and, therefore, the cellulolytic activity of certain fibrolytic bacteria such as Butyrivibrio fibrisolvens, Bacteroides succinogenes, Ruminococcus flavefaciens or Fibrobacter succinogenes. As a consequence, the Pyruvate-Acetyl-CoA-Acetate or the Pyruvate-Acetyl CoA-Aceto-acetyl CoAButyrate pathways would be favored over the Pyruvate-Lactate-Acrylate-Propionate pathway. This intra- and interspecific genetic variation in the ruminal ecosystem would also have the effect of changing the volatile fatty acid (VFA) excretion profile, thus influencing the final proteolytic status of the ruminal environment (Asplund, 1994; Van Soest, 1994; Sarmadi et al., 2016). Therefore, for methods that use ruminants directly (in vivo or in situ) or as donors of ruminal fluid (in vitro), it is suggested that the animals should be offered diets that are sufficiently balanced in terms of fiber (NDF), energy, minerals and nitrogenous sources to maintain a stable ruminal steady state with greater synchronization in the bioavailability of N/energy, and at the same time, a diet should be established that is as representative as possible of the production conditions under which the animals are fed (Nocek and Grant, 1987; Kaswari et al., 2007; Zagorakis et al., 2015).

Another phenomenon to be considered in the assays is the fact that the digestion of nitrogenous compounds in the rumen is particularly important during the periods following feeding; normally, a high percentage of the polypeptides are hydrolyzed during the first 6 to 8 hours after being subjected to the digestive action of microorganisms in the ruminal ecosystem. The extent and rates of this early degradation are directly associated with the solubility and the physical-chemical availability of the proteins in the food to be digested. It should be noted that, in the case of fresh forage, special consideration must be given to the activation of the endogenous proteases in the plant, which usually 
occurs after cutting or grazing. Furthermore, these endogenous enzymes may undergo induction in the rumen due to the anaerobic conditions and high temperature in the ruminal medium. Among the principal consequences of the activity of the endogenous proteases is autohydrolysis of the plant proteins, resulting in an increase in the concentration of soluble $\mathrm{N}$ in the medium, which would generate a kinetic moment that would overestimate microbial proteolytic activity and result in a mathematical bias in experiments used to determine lag times and hydrolysis rates $(k d)$. This situation is important in assays in which fresh forage is evaluated and may produce skewed predictions of real protein degradability in the rumen (Zhu et al., 1999; Kaswari et al., 2007; Riasi et al., 2008).

\section{Methodologies for predicting protein degradability in the rumen}

Today, various methodologies exist for predicting the extent and rates of protein degradation of feeds in the rumen. The most traditional are based on biological techniques, and the most representative of these are in vivo, in situ and in vitro. Chemical methodologies are also used, and one of the most common is the chemical fractioning of the proteins in a feed. Another currently available technique for this purpose is near infrared reflectance spectroscopy (NIRS), which is based on the physical principle that atoms and molecules exhibit electromagnetic vibrations when they are excited with lasers, allowing the determination of the wavenumbers of different materials (Belanche et al., 2013). When light strikes a sample, some photons may be transmitted through the material while the rest are reflected or absorbed by covalent bonds (Murray, 1993). When applied in the near infrared light spectrum, the results can provide information about the main structural elements associated with living organisms because the functional groups that respond to radiation in this spectrum are $\mathrm{CH}, \mathrm{OH}, \mathrm{NH}$ and, probably, $\mathrm{SH}$ and $\mathrm{C}=\mathrm{O}$ (Alomar and Fuchslocher, 1998). This makes it possible not only to learn the molecular structures of a feed but also to predict the degradation dynamics of its components.

One of the main chemical methods is that developed by Sniffen et al. (1992) and Licitra et al. (1996), who proposed a system for the chemical fractioning of proteins that was incorporated into the Cornell Net Carbohydrate and Protein System (CNCPS, 1992) and adopted by the NRC (2001) for their version of nutrient requirements and recommended feed composition for dairy cattle. This methodology establishes the chemical analysis of the nitrogenous fractions of a feed; its main characteristics being its ease of application and the reliability of its measurements. The measurement system establishes five nitrogenous fractions corresponding to $\mathrm{A}, \mathrm{B}_{1}, \mathrm{~B}_{2}, \mathrm{~B}_{3}$ and $\mathrm{C}$ pools, where: pool $\mathrm{A}=$ soluble in buffer, not precipitable with trichloroacetic acid (TCA), and corresponding to non-protein N (NPN); pool $\mathrm{B}_{1}=$ soluble in buffer and precipitable with TCA; pool $\mathrm{B}_{3}=$ insoluble in neutral detergent but soluble in acid detergent (difference between NDF-N and ADF-N); pool C= ADF-N, non-degradable or unavailable fraction (associated with lignin, tannins or the Maillard reaction); and pool $\mathrm{B}_{2}$ is calculated as the difference between total $\mathrm{N}$ and the other $\mathrm{N}$ pools. Fractions $\mathrm{A}_{1} \mathrm{~B}_{1}$ and $\mathrm{B}_{2}$ are normally associated with cell content, while fraction $\mathrm{B}_{3}$ is associated with plant cell walls. Despite the strengths of this technique, some aspects of the procedure have been criticized, mainly its methodological rigidity and the lack of representation of the biological phenomena that occur in the rumen (Stern et al., 1997; Mustafa et al., 2001). Moreover, some authors have reported large differences in the sizes of the different nitrogenous fractions between samples of a single type of feed, suggesting that local conditions and the method itself are major sources of variation in the characterization of these chemical fractions of proteins (Mullahey et al., 1992; Jones et al., 1995; Reed, 1995; Velásquez and Pichard, 2010b). Additionally, this technique does not allow for the hydrolysis rate $(k d)$ to be calculated as it does not yield different degradation 
levels for different kinetic periods. There is an unavoidable source of experimental error, which can skew the real value of fractions $\mathrm{A}_{\text {and }} \mathrm{B}_{1}$, that is related to the capability of TCA to precipitate polypeptides. Under this methodology, fraction A, which represents the whole of the NPN, could include low-molecular-weight polypeptides not precipitated by TCA, thus overestimating this nitrogenous fraction. According to Gabriel et al. (2008), the cut-off molecular weight for peptide precipitation by TCA is $3 \mathrm{kDa}$, and even higher molecular weight peptides might be randomly excluded from the fraction precipitated with TCA. In the case of pool $\mathrm{B}_{1}$, a reverse situation may occur as a result of the above; i.e., low-molecularweight peptides might not be included because they were not precipitated by TCA. This situation may be demonstrated by isolating these fractions and determining their molecular characteristics by electrophoresis.

The primary merit of biological methods is their proximity and their more direct representation of the ruminal ecosystem. The in vivo method is probably the oldest and one of the best known, and the simplest form of this technique allows the digestible protein (DP) to be estimated by subtracting the protein found in the feces from the total amount of protein consumed. Dividing this result by the total protein consumed and multiplying by 100 gives the apparent digestibility coefficient. The main limitation of this method is the uncertain and highly variable origin of the $\mathrm{N}$ found in the feces because it may be of endogenous origin (NMF), i.e., coming from ruminal microorganisms, and/or an undigested part from these two sources. It has been estimated that a ruminant excretes approximately 0.5-0.6 g of NMF in its feces for every $100 \mathrm{~g}$ of dry matter (DM) consumed. This figure represents close to $3.8 \mathrm{~g}$ of the crude protein (CP), so in a feed with low CP levels, the apparent digestibility coefficient will be strongly influenced by this effect. Therefore, there is a major limitation in the basic conception of this technique, and if we seek to estimate digestibility under grazing con- ditions, the situation becomes even more complex given the operational difficulties of the technique, firstly, in measuring the DM consumed and, secondly, in measuring the quantity of feces excreted. The result of these limitations is that the in vivo measurement of protein digestibility is inappropriate for routine use, and moreover, these measurements generally present low repeatability. Another important limitation of some in vivo protocols is the requirement for the ruminal and duodenal fistulation of the animal, which is problematic both for welfare reasons and because the samples taken by cannula are sometimes not representative and microbial contamination is inevitable during handling (Seymour et al., 1992). The in situ protein degradation method was developed to avoid the sources of error inherent in the in vivo method as it consists of the intra-ruminal incubation of dacron bags containing feed (Mehrez and Ørskov, 1977; Ørskov, 1992; Shannak et al., 2000; Pawelek et al., 2008; Zhang et al., 2015; Tayyab et al., 2016). This technique is one of the most traditional and representative for studying the proteolysis dynamics in the rumen. Its principal merit is the incubation protocol, which is directly applied in the ruminal ecosystem and is the protocol that is most frequently used today thus providing an important reference for the validation of alternative methods. It has been criticized, however, for the presence of various disturbing effects, the most important of which are microbial and N-compound contamination in the residue bags, the escape of particles from the bags into the ruminal medium, and the rarefication of the environment inside the bags (Mathis et al., 2001; Cone et al., 2004). One possibility for correcting particle loss from the bags into the ruminal medium is the method developed by Velásquez and Pichard (2010b) and modified from Weisbjerg et al. (1996), which states that the corrected $b$ fraction $(b c)=b+P(b(1-(P+$ $\mathrm{SN}))^{-1}$ ), where $\mathrm{b}$ is the nitrogenous fraction enzymatically degraded in situ (corrected, in turn, for microbial contamination); $\mathrm{P}$ is the particle loss from the bag into the ruminal medium; and $\mathrm{SN}$ is the soluble nitrogen. The particle loss is 
determined by the difference between the total material escaping from the bag after washing and the fraction of soluble $\mathrm{N}$ at time zero, so the total in situ protein degradation is equal to the sum of pool $\mathrm{A}+$ pool $\mathrm{B}_{1}+$ pool bc. This correction is an attempt to estimate the digestibility of the lost particles (P) if they had remained inside the bag and been digested in situ, and the estimate is performed by adding fraction $b$ to the expression $\mathrm{P}\left(\mathrm{b}(1-(\mathrm{P}+\mathrm{SN}))^{-1}\right.$, where $\mathrm{b}(1-(\mathrm{P}+\mathrm{SN}))^{-1}$ provides an estimate of the potential digestibility of the lost particles. On many occasions when the in situ technique is used to estimate protein digestibility, no correction is made for particle loss, causing - as may be appreciated from the above analysis - a serious skew in the measurement of the rumen digestibility potential of the proteins in a feed. Furthermore, when this in situ method is used, no correction is usually made for the microbial contamination present in the residues in sacco. In fact, during the colonization and adherence of the bacteria on the microparticles to be digested, a physical-chemical union is formed between these components that is hard to break and may persist in the undigested residues (after washing the bags upon their removal from the intra-ruminal medium). So, if the presence of microbial $\mathrm{N}$ in the bag residues is not corrected, the number of $\mathrm{N}$ atoms present in the undigested fraction of the feed will be overestimated. It should be noted that the microbial contamination can be corrected by various methods, which are mainly based on microbial markers, but the protocols are complex and not free of difficulties. Among these is the use of 2,6 diaminopimelic acid (DAPA), an amino acid that is only found in bacterial walls. One of the limitations is the high variation in the N:DAPA ratio, which leads to a quantitative bias in the estimation of the total $\mathrm{N}$ of microbial origin. Another alternative is the use of $D$-alanine, the stereoisomer of the amino acid $L$-alanine that is only present in bacteria (enantiomer of $L$-alanine), but this option also results in some variability in the $\mathrm{N}: D$-alanine ratio. In the case of protozoa, aminoethylphosphonic acid (AEPA) can be used, but this method may present some sources of error, such as the presence of the marker in other microorganisms and the remains of feed particles. The N:AEPA ratio also varies between protozoa species and genera. Then, there is the possibility of using the isotopes of some chemical elements as microbial markers, such as $\mathrm{N}^{15}, \mathrm{~S}^{35}$ or $\mathrm{P}^{32}$ (Robinson et al, 1996; D'Mello, 2000), which can be used for evaluations both in situ and in vitro. One of the reported limitations of this method is that enrichment with these isotopes is not homogeneous for among different groups of bacteria and protozoa, leading to large skews in the final measurements of microbial N. A simpler technique for correcting microbial contamination of in situ experiments is that used by Velásquez and Pichard (2010b), which consists of incubating bags similar to those used in the in situ assay and containing $500 \mathrm{mg}$ of sterile cotton wool. It is hypothesized that the microorganisms will adhere to the cellulose fibers of the cotton wool (free of N) simulating the colonization of feed particles. Thus, after the bags are washed using the same experimental protocol, only the microorganisms, especially the bacteria, will remain on the fibers, so all of the $\mathrm{N}$ measured in this residue will be of exclusively microbial origin. However, even if attempts are made to correct the principal limitations, uncontrollable skewness will probably persist with the in situ technique. For example, correction for particle loss may show some variability for the same feed because the kinetics of particle escape from the bag into the ruminal medium is unforeseeable and uncontrollable at the molecular level. It is possible to try to minimize this skew by using an appropriate, homogeneous grain size $(>2 \mathrm{~mm})$ for the samples, but the microparticle content and movement dynamic in the intra-sacco medium will continue to be unpredictable. The same will happen if microbial contamination is rigorously addressed as it is almost impossible to obtain high repeatability in the correction values for contaminant microbial biomass in bags incubated inside the rumen. Additionally, the pore size may affect the degree of digestion of the proteins inside the bags. The bags that are nor- 
mally used are made of dacron with a $50 \pm 15 \mu$ pore size, which supposes that there would be no problems for bacteria to enter the bags. However, ciliate protozoa measuring more than $50 \mu$ (e.g., Diplodinium, Epidinium, Isotricha) are known to exist and are therefore excluded from the degradation activity in sacco. This method eliminates their possible ecological interactions and hinders the direct digestive action of these protozoa.

In vitro methods involving ruminal fluid (Broderick, 1987; Hristov and Broderick, 1994; Luchini et al., 1996; Spanghero et al., 2015) are an attractive option from a biological point of view, but they present a series of limitations that increase their inaccuracy in predicting protein degradation. The main difficulty arises in separating feed protein from microbial protein (Broderick, 1987; Robinson et al., 1996), and different corrective variants have been attempt to address this difficulty. One is to use ruminal fluid that is free of live microorganisms (separated by centrifuging), but little proteolytic activity has been observed when this has been tried on different substrates (Luchini et al., 1996). The in vitro method with inhibited ruminal fluid (Inhibitor in vitro method - IIV) developed by Broderick (1987) is based on the inhibition of microbial protein synthesis with chloramphenicol and deamination with hydrazine sulfate. The protein degradation of the substrate is quantified by measuring the ammonium and total amino acids (TAA) released, discounting the corresponding blanks, but there are various criticisms of this method, some of which are reported by the authors (Broderick et al., 2004). Considerable variability in protein degradability was observed between incubations with ruminal fluid from the same donor animal under the same feed regimen, making it necessary to increase the number of replications to reduce the effects of these sources of error. The authors further report that measuring degraded protein by detection of only $\mathrm{NH}_{3}$ and TAA could underestimate the rate and extent of protein degradation. Wallace et al. (1999) and Choi et al. (2002) suggested that some peptides may act as important intermediaries during protein hydrolysis in the rumen and should therefore be considered as part of the degraded protein. Another source of variation is that proteolytic activity is generally substrate-induced, so the stimulation of microbial protein synthesis (peptidases) would be increased in the presence of a protein substrate. Therefore, the degradation potential of these microorganisms would then be negatively affected by the inhibition of their synthesis by chloramphenicol. One of the most important criticisms of this method is that the inhibition of microbial growth hinders modification of the biodiversity of the microorganisms in response to the nature of the feed to be digested, and furthermore, treatment with hydrazine probably provokes the death and lysis of many bacteria. This method is also limited by the short incubation time during which the protein degradability of the feed samples can be evaluated. After more than 8 to 10 hours, the environment in the incubation medium is severely rarefied, and the inhibitory properties of chloramphenicol and hydrazine sulfate fail (Broderick et al., 2004).

Another technique used for studies of proteolytic degradation in the rumen is based on commercial enzymes, basically the fungus Streptomyces griseus (Pichard and Van Soest, 1977; Mahadevan et al., 1987; Assoumani et al., 1992; Velásquez and Pichard, 2010b). Previous authors achieved high levels of protein degradation for various feed substrates using fungal proteases. However, this method has attracted some criticisms that are basically related to the insufficient biological representativeness of the proteolytic events occurring in the rumen because the fungus that gives rise to the proteases has a very different ecological niche compared to that of the microorganisms occurring naturally in the rumen. It also lacks a diverse carbohydrase and protease pool, limiting the enzymatic interactions that are fundamental to protein digestion in the ruminal ecosystem (Roe et al., 1991; Luchini et al., 1996; Stern et al., 1997; Velásquez and Pichard, 2010b). 
It is a permanent challenge to find new methods for predicting protein degradation in the rumen that not only provide laboratories with robust predictions but are easy to use, analytically satisfactory for a wide range of feed substrates and present high repeatability (Givens et al., 2000; Velásquez and Pichard, 2010a). To satisfy these conditions, an alternative method has been proposed that is based on enzymes extracted from the ruminal fluid (Mahadevan et al., 1987; Kohn and Allen, 1993 and 1995; Velásquez and Pichard, 2010a). Nevertheless, the absence of the biological processes involved in protein degradation in the rumen (induction and the microorganismsubstrate interaction) would be a limitation of this methodology because the enzyme extracts are free of microorganisms. It has been observed that certain specific adherence and colonization mechanisms are fundamental to the induction of enzyme secretion and activity in microorganisms. Moreover, techniques for enzyme extraction and purification from the ruminal fluid are not always optimal; in some cases, the enzymes are not very representative or occur at low concentrations. There are also problems with maintaining proteolytic activity during storage and with the persistence of hydrolysis during assays. Velásquez and Pichard (2010b) evaluated the proteolytic activity of mixtures of enzyme extracts generated from ruminal microorganisms cultured in vitro, and compared them with the method using proteases from Streptomyces griseus and the in situ technique. The ruminal fluid from which the enzyme extracts were generated was pre-incubated in vitro with different substrates to generate a higher enzyme concentration and promote a broad spectrum of hydrolytic activity (endo- and exoproteases, cellulases, pentosanases, pectinases and amylases). The enzyme extracts were evaluated by incubating $100 \mathrm{mg}$ each of crude protein (CP) from soybean meal, canola meal, sunflower meal, gluten feed, alfalfa meal, berseem clover, perennial ryegrass and oat forage (Avena sativa) in $30 \mathrm{ml}$ of Tris-HCl $50 \mathrm{mM}$ (pH 6.5) buffer at 39 ${ }^{\circ} \mathrm{C}$ for $48 \mathrm{~h}$. The ruminal enzymes presented an average degradation of $75.5 \%$ of the $\mathrm{CP}$ across the eight feeds, and this value was similar to that measured with proteases of Streptomyces griseus $(74.6 \% \mathrm{CP})$ but significantly lower $(\mathrm{P}<0.05)$ than with the in situ method $(84.8 \% \mathrm{CP})$. Degradation of soybean meal with ruminal enzymes was $85.6 \%$ with a degradation rate $(k d)$ of $6.6 \% / \mathrm{h}$, but with the in situ method, the values were $93.2 \%$ and 7.2 $\% / \mathrm{h}$, respectively. In both cases, the differences were significant $(\mathrm{P}<0.05)$. For alfalfa meal, the observed degradation was $77.6 \%$ with enzyme extracts and $84 \%$ with the in situ method, and the $k d$ values for these measurements were 8 and $9.5 \% / \mathrm{h}$, respectively. These methods differed significantly $(\mathrm{P}<0.05)$ for the previously mentioned kinetic parameters, and the results were generally similar for the other feeds evaluated with great variation in the values of the extent and rate of proteolytic degradation for the same feed when determined with different methods. Table 1 shows measurements of degradation and kinetic parameters in studies of ruminal protein degradability using different methods for the same feed (according to different authors). While errors due the experimental design or the preparation and origin of the feed samples will always arise, it might be expected that the results would be comparable. However, the values differ widely, for example, in soybean meal, perennial ryegrass, canola meal and alfalfa meal. These observed variations between different methodologies present an uncertainty when attempting to predict the real degradability of the proteins from a feed in the rumen. The ideal situation would be for very similar results to be obtained from the different methodological strategies with the same feed so that the inaccuracies of the predictions would be negligible. In reviewing the coefficients of variation $(\mathrm{CV})$ of the data on $\mathrm{CP}$ degradation for the same food among the methodologies presented in Table 1, it was generally observed that the in situ and enzymatic extracts from the ruminal fluid (ERF) techniques had the lowest values, indicating less heterogeneity between independent measurements using the same food. For example, the $\mathrm{CV}$ values for the methods in situ-soybean meal, in situ-alfalfa meal and in situ-canola meal 
were $15.79 ; 18.01$ and $9.32 \%$, respectively. In the cases of ERF-soybean meal, ERF-alfalfa meal and ERF-canola meal, these values were 48.52; 33.56 and $10.19 \%$, respectively. In contrast to the in vitro methodologies (ruminal fluid)-soybean meal and in vitro-alfalfa meal, the $\mathrm{CV}$ values were 63.04 and $49.87 \%$, respectively; while for the protease (Streptomyces griseus) technique, the CV for soybean meal it was $94.52 \%$. These values suggest that in situ and ERF techniques would present greater accuracy and reproducibility in their implementation given the greater homogeneity between the revised observations.

Methods based on infrared spectroscopy, notably NIRS (near infrared reflectance spectroscopy) and FTIR (Fourier-transform infrared spectroscopy) have greatly advanced the analysis of the chemical composition of feeds in recent years, particularly the prediction of protein degradability in the rumen. Although these methods are robust and can be applied to a wide variety of feeds, some limitations have been observed. This type of analysis provides chemical-structural information about the feed, allowing the chemical composition of and the kinetic processes that degrade ruminal food to be inferred (Andrés et al., 2005; Ohlsson et al., 2007). The FTIR technique has recently been developed; it is more sensitive than traditional methods, and data can be obtained more quickly (Belanche et al., 2013). These authors, in research on the "Estimation of feed crude protein concentration and rumen degradability by Fourier-transform infrared spectroscopy", which used PLS (partial least squares regression) models with SIMPLS algorithms, concluded that the use of this method is promising for the estimation of the concentration of $\mathrm{CP}$ and its degradation in the rumen. It was also found that the FTIR method was particularly accurate in predicting the $\mathrm{CP}$ concentration in forage and its degradation kinetics in the rumen. However, when the models were used to evaluate concentrates, the results were less robust, and ruminal $\mathrm{CP}$ degradation could only acceptably be estimated in protein-rich concentrates. Another interesting conclusion of this study was that the majority of FTIR-based predictions show a similar level of accuracy as the NIRS method, suggesting that FTIR should be considered as a low-cost alternative method for the nutritional evaluation of feeds. Although NIRS has demonstrated some capability for directly predicting the degradability of forage components in situ (Nordheim et al., 2007; Ohlsson et al., 2007), approximately 12,000 dacron bags would need to be processed for calibration purposes (Hoffman et al., 1999). Given this complexity, NIRS is proposed as a reliable technique for predicting the composition of incubation residues for which calibration requires fewer observations (Reeves et al., 1991; Berzaghi et al., 1997; Andrés et al., 2005).

In general, this review allows us to conclude that there is still no single method that complies with all of the requirements of representativeness, precision and accuracy. The ideal would be to establish a method that is sufficiently safe, robust, practical and flexible and that offers universal validity for application in any laboratory and to any feed type and can be adapted to the context of the production system used for the ruminants. Such a methodology would allow for feeding plans to be established that fit the needs of the animals as closely as possible. Table 2 shows a summary of the methods discussed above, together with their advantages and disadvantages and some suggestions for improvement. 
Table 1. Measurements of degradation and kinetic parameters in studies on ruminal protein degradability with different methods according to feed and authors.

\begin{tabular}{|c|c|c|c|c|c|}
\hline Method & Substrate & Incubation time $(\mathrm{h})$ & Degradation $(\% \mathrm{CP})$ & $\begin{array}{c}K d^{I 0} \\
(\% / \mathrm{h})\end{array}$ & Reference \\
\hline In situ & Soybean meal & 24 & 66.50 & & Assoumani et al. (1992) \\
\hline In situ & Soybean meal & 24 & 75.80 & & Calsamiglia et al. (1992) \\
\hline In situ & Soybean meal & 48 & 99.30 & 9.4 & NRC (2001) \\
\hline In situ & Soybean meal & 48 & 93.17 & 7.2 & Velásquez and Pichard (2010b) \\
\hline In situ & Soybean meal & 48 & 98.20 & 12.9 & Habib et al. (2013) \\
\hline In situ & Soybean meal & 48 & 90.20 & & Tuncer and Sacakli (2003) \\
\hline In situ & Soybean meal & 48 & 98.20 & 12.9 & Habib et al. (2013) \\
\hline In situ & Soybean meal & 48 & 62.00 & 8.4 & Akbarian et al. (2014) \\
\hline In situ & Roasted soybean & 48 & 50.70 & 6.1 & Akbarian et al. (2014) \\
\hline In situ & Roasted soybean & 48 & 50.70 & 6.1 & Akbarian et al. (2014) \\
\hline In situ (ERD) $)^{1}$ & Soybean meal & 48 & 54.60 & & Tuncer and Sacakli (2003) \\
\hline In situ (ERD) $)^{1}$ & Soybean meal & 48 & 75.00 & 12.9 & Habib et al. (2013) \\
\hline In situ (ERD) $)^{1}$ & Soybean meal & 48 & 75.00 & 12.9 & Habib et al. (2013) \\
\hline In situ $(\mathrm{FTIR})^{2}$ & Soybean meal & 96 & 61.00 & 4.4 & Belanche et al. (2013) \\
\hline In vitro $(\mathrm{RFI})^{3}$ & Soybean meal & 4 & 48.00 & & Broderick et al. (2004) \\
\hline In vitro $(\mathrm{RFI})^{3}$ & Soybean meal & 4 & 18.40 & & Broderick (1987) \\
\hline Enzymatic (ERF) ${ }^{4}$ & Soybean meal & 16 & 47.30 & & Kohn and Allen (1995) \\
\hline Enzymatic $(\mathrm{ERF})^{4}$ & Soybean meal & 6 & 37.90 & & Kohn and Allen (1995) \\
\hline Enzymatic $(\mathrm{ERF})^{4}$ & Soybean meal & 6 & 25.50 & & Mahadevan et al. (1987) \\
\hline Enzymatic (ERF) ${ }^{4}$ & Soybean meal & 48 & 83.00 & 5.9 & Velásquez and Pichard (2010a) \\
\hline Enzymatic $(\mathrm{ERF})^{4}$ & Soybean meal & 48 & 85.58 & 6.6 & Velásquez and Pichard (2010b) \\
\hline Proteases $\mathrm{Sg}^{5}$ & Soybean meal & 48 & 84.52 & 5.9 & Velásquez and Pichard (2010b) \\
\hline Proteases $\mathrm{Sg}^{5}$ & Soybean meal & 6 & 16.80 & & Mahadevan et al. (1987) \\
\hline $\mathrm{CFP}^{6}$ & Soybean meal & & 94.46 & & Velásquez and Pichard (2010b) \\
\hline $\mathrm{CFP}^{6}$ & Soybean meal & & 68.30 & & Akbarian et al. (2014) \\
\hline $\mathrm{CFP}^{6}$ & Roasted soybean & & 92.20 & & Akbarian et al. (2014) \\
\hline In situ & Alfalfa meal & 48 & 90.60 & 10.8 & NRC (2001) \\
\hline In situ & Alfalfa meal & 48 & 83.95 & 9.5 & Velásquez and Pichard (2010b) \\
\hline In situ & Alfalfa meal & 48 & 67.35 & 9.0 & Cobellis et al. (2015) \\
\hline In situ & Alfalfa meal & 48 & 57.37 & 26.0 & Cobellis et al. (2015) \\
\hline In situ & Alfalfa meal & 48 & 70.27 & 14.0 & Cobellis et al. (2015) \\
\hline In situ $(\mathrm{ERD})^{7}$ & Alfalfa meal & 48 & 64.24 & & Cobellis et al. (2015) \\
\hline In situ $(\mathrm{ERD})^{7}$ & Alfalfa meal & 48 & 56.80 & & Cobellis et al. (2015) \\
\hline In situ $(\mathrm{ERD})^{7}$ & Alfalfa meal & 48 & 65.35 & & Cobellis et al. (2015) \\
\hline In vitro $(R F I)^{3}$ & Alfalfa meal & 4 & 21.20 & & Broderick et al. (2004) \\
\hline In vitro $(\mathrm{RFI})^{3}$ & Alfalfa meal & 6 & 44.30 & & Peltekova and broderick (1996) \\
\hline Enzymatic $(\mathrm{ERF})^{4}$ & Alfalfa meal & 16 & 41.70 & & Kohn and Allen (1995) \\
\hline Enzymatic $(E R F)^{4}$ & Alfalfa meal & 6 & 38.20 & & Kohn and Allen (1995) \\
\hline Enzymatic $(\mathrm{ERF})^{4}$ & Alfalfa meal & 48 & 55.30 & 5.9 & Velásquez and Pichard (2010a) \\
\hline Enzymatic $(\mathrm{ERF})^{4}$ & Alfalfa meal & 48 & 77.58 & 8.0 & Velásquez and Pichard (2010b) \\
\hline Proteases $\mathrm{Sg}^{5}$ & Alfalfa meal & 48 & 76.45 & 7.2 & Velásquez and Pichard (2010b) \\
\hline Proteases $\mathrm{Sg}^{5}$ & Alfalfa meal & 48 & 75.90 & & Mathis et al. (2001) \\
\hline $\mathrm{CFP}^{6}$ & Alfalfa meal & & 87.64 & & Velásquez and Pichard (2010b) \\
\hline
\end{tabular}


Continuation Table 1

\begin{tabular}{|c|c|c|c|c|c|}
\hline In vitro $(\mathrm{RFI})^{3}$ & BSA & 4 & 54.00 & & Broderick (1987) \\
\hline Enzymatic (ERF) ${ }^{4}$ & BSA & 6 & 73.60 & & Velásquez and Pichard (2010a) \\
\hline Enzymatic $(E R F)^{4}$ & BSA & 12 & 78.50 & & Velásquez and Pichard (2010a) \\
\hline In situ & Canola meal & 48 & 99.00 & 4.4 & NRC (2001) \\
\hline In situ & Canola meal & 48 & 89.08 & 7.0 & Velásquez and Pichard (2010b) \\
\hline In situ & Canola meal & 48 & 78.70 & 17.0 & Xin and Yu (2014) \\
\hline In situ & Canola meal & 48 & 90.30 & & Tuncer and Sacakli (2003) \\
\hline In situ $(\mathrm{ERD})^{1}$ & Canola meal & 48 & 77.20 & & Tuncer and Sacakli (2003) \\
\hline Enzymatic (ERF) ${ }^{4}$ & Canola meal & 48 & 78.56 & 6.4 & Velásquez and Pichard (2010b) \\
\hline Enzymatic (ERF) ${ }^{4}$ & Canola meal & 48 & 68.00 & 5.5 & Velásquez and Pichard (2010a) \\
\hline Proteases $\mathrm{Sg}^{5}$ & Canola meal & 48 & 76.09 & 5.8 & Velásquez and Pichard (2010b) \\
\hline $\mathrm{CFP}^{6}$ & Canola meal & & 93.52 & & Velásquez and Pichard (2010b) \\
\hline In situ & $\begin{array}{l}\text { Perennial } \\
\text { Ryegrass }\end{array}$ & 48 & 75.38 & 11.0 & Velásquez and Pichard (2010b) \\
\hline Enzymatic $(E R F)^{4}$ & $\begin{array}{l}\text { Perennial } \\
\text { Ryegrass }\end{array}$ & 48 & 46.80 & 6.4 & Velásquez and Pichard (2010a) \\
\hline Enzymatic $(E R F)^{4}$ & $\begin{array}{l}\text { Perennial } \\
\text { Ryegrass }\end{array}$ & 48 & 68.72 & 10.1 & Velásquez and Pichard (2010b) \\
\hline Proteases $\mathrm{Sg}^{5}$ & $\begin{array}{l}\text { Perennial } \\
\text { Ryegrass }\end{array}$ & 48 & 67.46 & 7.7 & Velásquez and Pichard (2010b) \\
\hline $\mathrm{CFP}^{6}$ & $\begin{array}{l}\text { Perennial } \\
\text { Ryegrass }\end{array}$ & - & 81.30 & & Velásquez and Pichard (2010b) \\
\hline In situ & $\mathrm{ASTFR}^{8}$ & 72 & 94.00 & & Geron et al. (2007) \\
\hline $\mathrm{CFP}^{6}$ & ASTFR $^{8}$ & & 99.50 & & Geron et al. (2007) \\
\hline In situ & FSTFR $^{9}$ & 72 & 96.00 & & Geron et al. (2007) \\
\hline $\mathrm{CFP}^{6}$ & FSTFR $^{9}$ & & 99.70 & & Geron et al. (2007) \\
\hline In situ & Sunflower meal & 48 & 91.70 & 24.7 & Habib et al. (2013) \\
\hline In situ $(\mathrm{ERD})^{1}$ & Sunflower meal & 48 & 82.60 & 24.7 & Habib et al. (2013) \\
\hline In situ & $\begin{array}{l}\text { Corn gluten } \\
\text { meal }\end{array}$ & 48 & 98.00 & 6.0 & Habib et al. (2013) \\
\hline In situ (ERD) ${ }^{1}$ & $\begin{array}{l}\text { Corn gluten } \\
\text { meal }\end{array}$ & 48 & 71.20 & 6.0 & Habib et al. (2013) \\
\hline In situ & Wheat bran & 48 & 88.20 & 28.1 & Habib et al. (2013) \\
\hline In situ $(\mathrm{ERD})^{1}$ & Wheat bran & 48 & 82.30 & 28.1 & Habib et al. (2013) \\
\hline In situ & Fish meal & 48 & 81.00 & 5.4 & Habib et al. (2013) \\
\hline In situ (ERD) ${ }^{1}$ & Fish meal & 48 & 59.60 & 5.4 & Habib et al. (2013) \\
\hline
\end{tabular}

${ }^{1}$ ERD, Efective rumen degradability: ruminal passage rate $=0.05 / \mathrm{h}$.

${ }^{2}$ FTIR, Fourier-Transform Infrared Spectrometers: calibration.

${ }^{3}$ RFI, Ruminal Fluid Inhibitor in vitro method - IIV.

${ }^{4}$ ERF, Enzymatic extracts from ruminal fluid.

${ }^{5}$ Proteases Sg, proteases from Streptomyces griseus.

${ }^{6} \mathrm{CFP}$, Chemical fractionation of proteins.

${ }^{7}$ ERD, Efective rumen degradability: ruminal passage rate $=0.02 / \mathrm{h}$.

${ }^{8}$ ASTFR, Acid silage of tilapia filleting residue.

${ }^{9}$ FSTFR, Fermented silage of tilapia filleting residue.

${ }^{10} \mathrm{Kd}$, degradation rate. 
Table 2. Methods for predicting ruminal protein degradability and their principal advantages and limitations.

\begin{tabular}{|c|c|c|c|}
\hline Method & Advantages & Limitations & References \\
\hline $\begin{array}{l}\text { Chemical protein } \\
\text { fractioning }\end{array}$ & $\begin{array}{l}\text {-High repeatability. } \\
\text {-Standardized method with a high } \\
\text { degree of control over empirical } \\
\text { conditions. } \\
\text {-No restrictions on the number and } \\
\text { type of feeds to be evaluated. }\end{array}$ & $\begin{array}{l}\text {-No biological representativeness. } \\
\text {-Variability in the results of analyses } \\
\text { of the same feed. } \\
\text {-Probable skews in the capacity for } \\
\text { peptide precipitation by TCA. } \\
\text {-Difficulty in calculating hydrolysis } \\
\text { rates }(k d) \text {. }\end{array}$ & $\begin{array}{l}\text { Sniffen et al. (1992); } \\
\text { Licitra et al. (1996). }\end{array}$ \\
\hline $\begin{array}{l}\text { In vivo: } \\
\text {-Analysis } \\
\text { of feces. } \\
\text {-Ruminal and } \\
\text { duodenal fistula }\end{array}$ & $\begin{array}{l}\text {-High biological representativeness } \\
\text { of the ruminal ecosystem. } \\
\text {-Allows for more real evaluation } \\
\text { by studying forage under grazing } \\
\text { conditions. }\end{array}$ & $\begin{array}{l}\text { - Need for ruminal and duodenal } \\
\text { fistulation. } \\
\text {-Microbial contamination in the feces } \\
\text { and endogenous } \mathrm{N} \text { in the undigested } \\
\text { residues. } \\
\text {-Laborious protocols. } \\
\text {-Control of consumption of the feed } \\
\text { sample to be evaluated. } \\
\text {-Variability in } \mathrm{N} \text { measurement by } \\
\text { microbial markers. }\end{array}$ & $\begin{array}{l}\text { Lu et al. (1988); Satter } \\
\text { (1986); Seymour } \text { et al. } \\
\text { (1992). }\end{array}$ \\
\hline In situ & $\begin{array}{l}\text { - Directly representative of the } \\
\text { ruminal environment. } \\
\text { - Simultaneous evaluation of } \\
\text { different feed samples under in } \\
\text { sacco conditions. } \\
\text {-No restrictions on the type of feeds } \\
\text { to be evaluated. }\end{array}$ & $\begin{array}{l}\text { - Particle loss from the bags. } \\
\text { - Microbial contamination of the } \\
\text { residue in sacco. } \\
\text { - Rarefication of the environment in } \\
\text { sacco. } \\
\text { - Lack of a balanced diet to maintain a } \\
\text { stable environment in the rumen. } \\
\text {-Variability in N measurements with } \\
\text { microbial markers. }\end{array}$ & $\begin{array}{l}\text { Mehrez and Ørskov } \\
\text { (1977); Ørskov } \\
\text { (1992); Pawelek et al. } \\
\text { (2008). }\end{array}$ \\
\hline $\begin{array}{l}\text { In vitro with ruminal } \\
\text { fluid (with and } \\
\text { without inhibition) }\end{array}$ & $\begin{array}{l}\text {-Easy to operate and obtain results. } \\
\text {-Uses live ruminal microorganisms } \\
\text { under simulated ruminal conditions. } \\
\text {-Allows for a large number } \\
\text { of samples to be evaluated } \\
\text { simultaneously; no restrictions on } \\
\text { the type of feed to be evaluated. }\end{array}$ & $\begin{array}{l}\text {-Difficulty of separating microbial } \\
\text { protein from that present in the feed. } \\
\text {-Variability in the extent and rate of } \\
\text { protein degradation of a feed between } \\
\text { incubations with ruminal fluid from } \\
\text { the same donor animal. } \\
\text {-Measuring degraded protein by } \\
\text { detection of only } \mathrm{NH}_{3} \text { and total } \\
\text { amino acids (TAA) released could } \\
\text { underestimate protein degradation. } \\
\text {-Inhibiting microorganism growth } \\
\text { prevents alterations in the microbial } \\
\text { biodiversity in response to the type of } \\
\text { feed digested. } \\
\text {-The useful evaluation time is } \\
\text { very short (8-10 hours) because } \\
\text { the incubation medium becomes } \\
\text { rarefied, and the inhibitory properties } \\
\text { of chloramphenicol and hydrazine } \\
\text { sulfate fail. }\end{array}$ & $\begin{array}{l}\text { Broderick (1987); } \\
\text { Luchini et al. (1996); } \\
\text { Broderick et al. } \\
(2004) \text {. }\end{array}$ \\
\hline $\begin{array}{l}\text { In vitro (commercial } \\
\text { enzymes) }\end{array}$ & $\begin{array}{l}\text { - Easy empirical application. } \\
\text { - No animals needed for empirical } \\
\text { use. } \\
\text { - No limitations on the number of } \\
\text { samples and type of feed. }\end{array}$ & $\begin{array}{l}\text { - Limited hydrolytic enzyme } \\
\text { spectrum. } \\
\text { - Origin of enzymes is not } \\
\text { representative of the ruminal } \\
\text { ecosystem. } \\
\text { - Lack of biological actions of the } \\
\text { organisms due to the absence of the } \\
\text { colonization, adherence and digestion } \\
\text { process. }\end{array}$ & $\begin{array}{l}\text { Pichard and Van Soest } \\
\text { (1977); Mahadevan et } \\
\text { al. (1987); Assoumani } \\
\text { et al. (1992). }\end{array}$ \\
\hline
\end{tabular}


Continuation Table 2

\begin{tabular}{|c|c|c|c|}
\hline $\begin{array}{l}\text { In vitro (ruminal } \\
\text { enzymes) }\end{array}$ & $\begin{array}{l}\text { - Practical method; easy to use with } \\
\text { good repeatability. } \\
\text { - No animals needed for empirical } \\
\text { use. } \\
\text { - Good biological } \\
\text { representativeness; the enzymes } \\
\text { come from ruminal microorganisms. } \\
\text { - No limitations on the number of } \\
\text { samples and the type of feed. }\end{array}$ & $\begin{array}{l}\text { - No biological processes associated } \\
\text { with the substrate-microorganism } \\
\text { interaction. } \\
\text { - Insufficient variability and } \\
\text { concentration of hydrolytic enzymes } \\
\text { (proteolytic-carbohydrolytic). } \\
\text { - Deficient extraction and purification } \\
\text { of enzymes from the ruminal fluid. } \\
\text { - Loss of enzyme activity and } \\
\text { hydrolytic persistence during storage. }\end{array}$ & $\begin{array}{l}\text { Mahadevan et al. } \\
\text { (1987); Kohn and } \\
\text { Allen (1993 and } \\
\text { 1995); Velásquez and } \\
\text { Pichard (2010a and } \\
\text { 2010b). }\end{array}$ \\
\hline NIRS; FTIR & $\begin{array}{l}\text { - Practical method with high } \\
\text { repeatability of results. } \\
\text { - No animals or other biological } \\
\text { material (enzymes, microorganisms) } \\
\text { needed for application. } \\
\text { - No restriction on the number of } \\
\text { samples evaluated. } \\
\text { - Can be applied to any type of feed. }\end{array}$ & $\begin{array}{l}\text { - Large number of samples needed for } \\
\text { calibration. } \\
\text { - Low protein content in the sample } \\
\text { may limit the effectiveness of the } \\
\text { technique. }\end{array}$ & $\begin{array}{l}\text { Andrés et al. }(2005) \text {; } \\
\text { Nordheim et al. } \\
\text { (2007); Ohlsson et al. } \\
\text { (2007); Belanche et } \\
\text { al. }(2013) \text {. }\end{array}$ \\
\hline
\end{tabular}

\title{
Resumen
}

\begin{abstract}
A. Velásquez, J. Rivero, y P.G. Marnet. 2016. Atributos y limitaciones empíricas de metodologías para predecir la degradabilidad ruminal de las proteínas. Cien. Inv. Agr. 43(2):171-189. El objetivo de esta revisión es analizar las metodologías comúnmente usadas para estimar la degradabilidad de las proteínas en el rumen, resaltando sus atributos y limitaciones en orden a ofrecer algunas sugerencias para mejorar su utilización. Esta información es esencial para seleccionar los tipos de alimentos cuando se formulan las dietas alimenticias. Una confiable predicción de la digestibilidad de las proteínas en el rumen constituye una información básica para optimizar el uso de los recursos nitrogenados, pudiendo por un lado traducirse en una mayor producción de leche, proteína láctea, carne o lana, y por otro, en una menor excreción de compuestos nitrogenados al ambiente; esta mayor eficiencia también tiene un impacto sobre la salud y el bienestar animal. Tradicionalmente, la digestibilidad ruminal de las proteínas de los alimentos ha sido predicha a través de métodos in vivo, in situ e in vitro. Sin embargo, otras técnicas han sido desarrolladas, basadas sobre espectroscopía infraroja, destacando los métodos NIRS y FTIR. Todas estas técnicas presentan limitaciones, factores perturbadores o fuentes de error, las cuales podrían generar predicciones sesgadas e inseguras. Los métodos in situ e in vitro, utilizando extractos enzimáticos de origen ruminal, y FTIR, probablemente poseen las mayores ventajas, no obstante, estas técnicas requieren ser perfeccionadas a través de futuras investigaciones.
\end{abstract}

\section{References}

Alomar, D., and R. Fuchslocher. 1998. Fundamentos de la espectroscopía de reflectancia en el infrarrojo cercano (NIRS) como método de análisis de forraje. Agrosur 26: 88-104.

Akbarian, A., M. Khorvash, G. R. Ghorbani, E. Ghasemi, M. Dehghan-Banadaky, P. Shawrang, and M. H. Ghaffari. 2014. Effects of roasting and electron beam irradiating on protein characteristics, ruminal degradability and intestinal digest- ibility of soybean and the performance of dairy cows. Livestock Science 168: 45-52.

Andrés, S., A. Calleja, R. Peláez, A.R. Mantecón, and F.J. Giráldez. 2005. How can NIRS method be used to predict in situ crude protein and neutral detergent fiber degradation in herbage? Journal of Animal and Feed Sciences 14: 727-736.

Asplund, J.M. 1994. Principles of Protein Nutrition of Ruminants. Animal Science Research Center. University of Missouri. Columbia. USA. CRC Press. 5:71-111. 
Assoumani, M.B., F. Vedeau, L. Jacquot, and C.J. Sniffen. 1992. Refinement of an enzymatic method for estimating the theoretical degradability of proteins in feedstuffs for ruminants. Anim. Feed Sci. Technol. 39:357-368.

Belanche, A., M.R. Weisbjerg, G.G. Allison, C. J. Newbold, and J. M. Moorby. 2013. Estimation of feed crude protein concentration and rumen degradability by Fourier-transform infrared spectroscopy. J. Dairy Sci. 96: 7867-7880.

Benninghoff, J., M. Paschke-Beese, and K.H. Südekum. 2015. In situ and in vitro ruminal degradation of maize grain anduntreated or xylose-treated wheat, barley and rye grains. Animal Feed Science and Technology 210: 86-93.

Berzaghi, P., G. Cozzi, and I. Andrighetto. 1997. The use of near-infrared analysis for in situ studies. Journal of Dairy Science 80: 3263-3270.

Broderick, G.A. 1987. Determination of protein degradation rates using a rumen in vitro system containing inhibitors of microbial nitrogen metabolism. Br. J. of Nutr. 58:463-475.

Broderick, G.A., P. Udén, M.L. Murphy, and A. Lapins. 2004. Sources of variation in rates of in vitro ruminal protein degradation. J. Dairy Sci. 87: 1345-1359.

Bull, L.S. 2001. Ruminant Protein Nutrition-Basic and Application. Animal and Poultry Waste Management Center. XXVI Reunión Annual Sociedad Chilena de Producción Animal. Santiago, Chile. p. 207-215.

Calsamiglia, S., M.D. Stern, and B.A. Crooker. 1992. Effects of diets formulated to contain different amounts of rumen non-degradable protein on microbial fermentation and nutrient flow from a continuos culture system. Anim. Feed Sci. Tech. 39:239-252.

Castro-Montoya, J., A. Henke, J. Molkentin, K. Knappstein, A. Susenbeth, and U. Dickhoefer. 2016. Relationship between milk odd and branched-chain fatty acids and urinary purine derivatives in dairy cows supplemented with quebracho tannins-A study to test milk fatty acids as predictors of rumen microbial protein synthesis. Animal Feed Science and Technology 214: 22-33.
Chamberlain, D.G., and J.J. Choung. 1995. The importance of rate of ruminal fermentation of energy sourges in diets for dairy cows. Recent Advances in Animal Nutrition 1:3-27.

Choi, C.W., S. Ahvenjarvi, A. Vanhatalo, V. Toivonen, and P. Huhtanen. 2002. Quantitation of the flow of soluble non-ammonia nitrogen entering the omasal canal of dairy cows fed grass silage based diets. Anim. Feed Sci. Technol. 96:203-220.

CNCPS. 1992. Cornell Net Carbohydrate and Protein System. In: Sniffen, C.J., J.D. O’Connor, P.J. Van Soest, D.G. Fox, and J.B. Russell, 1992. A net carbohydrate and protein system for evaluating cattle diets: II. Carbohydrate and protein availability. J. Anim. Sci. 70:3562-3577.

Cobellis, G., G. Acuti, C. Forte, L. Menghini, S. De Vincenzi, M. Orrù, A. Valiani, D. Pacetti, and M. Trabalza-Marinucci. 2015. Use of Rosmarinus officinalis in sheep diet formulations: Effects on ruminal fermentation, microbial numbers and in situ degradability. Small Ruminant Research 126: $10-18$.

Cone, J.W., A.H. van Gelder, A.A. MathijssenKamman, and V.A. Hindle. 2004. Rumen escape protein in grass and grass silage determined with a nylon bag and an enzymatic technique. Anim. Feed Sci. Tech. 111: 1-9.

Costa, C.T.F., M.A. Ferreira, J.M.S. Campos, A. Guim, J.L. Silva, M.C.B. Siqueira, L.J.A. Barros, and T.D.Q. Siqueira. 2016. Intake, total and partial digestibility of nutrients, and ruminal kinetics in crossbreed steers fed with multiple supplements containing spineless cactus enriched with urea. Livestock Science 188: 55-60.

D'Mello, J.P.F. 2000. Farm Animal Metabolism and Nutrition. Biotechnology Department The Scottish Agricultural College. Edinburg UK. 12: 255-277.

Encinias, A.M., G.P. Lardy, J.L. Leupp, H.B. Encinias, L.P. Reynolds, and J.S. Caton. 2005. Efficacy of using a combination of rendered protein products as an undegradable intake protein supplement for lactating, winter-calving, beef cows fed bromegrass hay. J. Anim. Sci. 83:187-195.

Gabriel, I., M. Lessire, H. Juin, J. Burstin, G. Duc, L. Quillien, J.N. Thibault, M. Leconte, J.M. Hallouis, P. Ganier, N. Mézière, and B. Sève. 
2008. Variation in seed protein digestion of different pea (Pisum sativum L.) genotypes by cecectomized broiler chickens: 1. Endogenous amino acid losses, true digestibility and in vitro hydrolysis of proteins. Livestock Science 113: 251-261.

Geron, L.J., L. M. Zeoula, R. M. Vidotti, M. Matsushita, R. Kazama, S. F. Caldas, and F. Fereli. 2007. Chemical characterization, dry matter and crude protein ruminal degradability and in vitro intestinal digestion of acid and fermented silage from tilapia filleting residue. Animal Feed Science and Technology 136: 226-239.

Givens, D.I., E. Owen, R.F.E. Oxford, and H.M. Omed. 2000. Forage Evaluation In Ruminant Nutrition. UK Biddles Ltd, Guildford and King's Lynn. 480 pp.

Habib, G., N.A. Khan, M. Ali, and M. Bezabih. 2013. In situ ruminal crude protein degradability of byproducts from cereals, oil seeds and animal origin. Livestock Science 153: 81-87.

Hao, X.Y., H.S. Xin, H. Gao, X.Y. Zhang, C. Lin, W.B. Xu, Y.Z. Wang, and Y.G. Zhang. 2016. Relationship between the physical parameters, chemical compositions and rumen degradation kinetics parameters of certain feedstuffs for ruminants. Animal Feed Science and Technology 211: 84-91.

Hoffman, P.C., N.M. Brehm, J.J. Hasler, L.M. Bauman, J.B. Peters, D.K. Combs, R.D. Shaver, and D.J. Undersander. 1999. Development of a novel system to estimate protein degradability in legume and grass silages. Journal of Dairy Science 82: 771-779.

Hristov, A., and G.A. Broderick. 1994. In vitro determination of ruminal protein degradability using [15N]-ammonia to correct for microbial nitrogen uptake. J. Anim. Sci. 72:1344-1353.

Hristov, A.N., C.E. Basel, A. Melgar, A.E. Foley, J.K. Ropp, C.W. Hunt, and J.M. Tricarico. 2008. Effect of exogenous polysaccharide-degrading enzyme preparations on ruminal fermentation and digestibility of nutrients in dairy cows. Animal Feed Science and Technology 145: 182-193. Hungate, R.E. 1966. The rumen and its microbes. Academic Press, N.Y.
Jones, B.A., R.E. Muck, and R.D. Hatfield. 1995. Red clover extracts inhibit legume proteolysis. J. Sci. Food and Agric. 67: 329-333.

Kaswari, T., P. Lebzien, G. Flachowsky, and U. Meulen. 2007. Studies on the relationship between the synchronization index and the microbial protein synthesis in the rumen of dairy cows. Animal Feed Science and Technology 139: 1-22.

Kohn, R.A., and M.S. Allen. 1993. An in vitro method to measure protein degradation of feeds for ruminants using enzymes extracted from rumen contents. Michigan State University, East Lansing. J. Dairy Sci. 76 (supl.1): 175 Abstract.

Kohn, R.A., and M.S. Allen. 1995. In vitro protein degradation of feeds using concentrated enzymes extracted from rumen contents. Anim. Feed Sci. Tech. 52: 15-28.

Kornegay, E.T. 1996. Nutrient Management of Food Animals to Enhance and Protect the Environment. Lewis Publishers 11: 151-165.

Licitra, G., T.M. Hernandez, and P.J. Van Soest. 1996. Standardization of procedures for nitrogen fractions of ruminant feeds. Anim. Feed Sci. Technol. 57: 347-358.

Lu, C.D., N.A. Jorgensen, and L.D. Satter. 1988. Site and Extent of Nutrient Digestion in Lactating Dairy Cows Fed Alfalfa Protein Concentrate or Soybean Meal. Journal of Dairy Science 71: 697-704.

Luchini, N.D., G.A. Broderick, and D.K. Combs. 1996. Characterization of the proteolytic activity of commercial proteases and strained ruminal fluid. J. Anim. Sci. 74:685-692.

Mahadevan, S., J.D. Erfle, and F.D. Sauer. 1987. Preparation of protease a. from mixed rumen microorganism and its use for the in vitro $b$. determination of the degradability of true protein in feedstuffs. Can. J. Anim. Sci. 67:55-64.

Mathis, C.P., R.C. Cochran, E.S. Vanzant, I.E.O. Abdelgadir, J.S. Held, K.C. Olson, D.E. Johnson, J. Caton, D. Faulkner, G. Horn, S. Paisley, R. Mass, K. Moore, and J. Halgerson. 2001. A collaborative study comparing an in situ protocol with single time- point enzyme assays for estimating ruminal protein degradability of different forages. Anim. Feed Sci. Tech. 93:31-42. 
Mehrez, A.Z., and E.R. Ørskov. 1977. A study of the artificial fibre bag technique for determining the digestibility of feeds in the rumen. J. Agric. Sci. 88:645-650.

Mullahey, J.J., S.S. Walker, K.J. Moore, L.E. Moser, and T.J. Klopfestein. 1992. In situ ruminal protein degradation of switchgrass and smooth bromegrass. Agronomy J. 183-188.

Murray, I. 1993. Forage Analysis by Near InfraRed Reflectance Spectroscopy. In: Davies, Baker, Grant and Laidlaw (Eds.), Sward Measurement Handbook, Second Ed., British Grassland Soc. p. 285-312.

Mustafa, A.F., D.A. Christensen, and J.J. McKinnon. 2001. Ruminal degradability of neutral detergent insoluble protein of selected protein sources. Can. J. Anim. Sci. 81:601-603.

Nocek, J.E., and A.L. Grant. 1987. Characterization of in situ nitrogen and fiber digestion and bacterial nitrogen contamination of hay crop forages preserved at different dry matter percentages. J. Anim. Sci. 64:552-564.

Nordheim, H., H. Volden, G. Fystro, and T. Lunnan. 2007. Prediction of in situ degradation characteristics of neutral detergent fiber (aNDF) in temperate grasses and red clover using near-infrared reflectance spectroscopy (NIRS). Animal Feed Science and Technology 139: 92-108.

NRC. 2001. Nutrient Requirement of Dairy Cattle. 7th Rev. Ed. National Academic Press, National Research Council. Washington DC. p. 405.

Ohlsson, C., L.P. Houmøller, M.R. Weisbjerg, P. Lund, and T. Hvelplund. 2007. Effective rumen degradation of dry matter, crude protein and neutral detergent fiber in forage determined by near infrared reflectance spectroscopy. Journal of Animal Physiology and Animal Nutrition 91: 498-507.

Ørskov, E.R. 1992. Protein Nutrition in Ruminants. $2^{\circ}$ E. Academic Press. The Rowett Research Institute Aberdeen. p. 171.

Pawelek, D.L., J.P. Muir, B.D. Lambert, and R.D. Wittie. 2008. In sacco rumen disappearance of condensed tannins, fiber, and nitrogen from herbaceous native Texas legumes in goats. Animal Feed Science and Technology 142: 1-16.
Peltekova, V.D., and G.A. Broderick. 1996. In vitro ruminal degradation and synthesis of protein on fractions extracted from alfalfa hay and silage. J. Dairy Sci. 79: 612-619.

Pichard, D.G., and P.J. Van Soest. 1977. Protein solubility of ruminant feeds. Proceedings of Cornell Nutrition Conf., Ithaca, N.Y. p: 91-98.

Razzaghi,A., M. Larsen, P. Lund, and M.R. Weisbjerg. 2016. Effect of conventional and extrusion pelleting on in situ ruminal degradability of starch, protein, and fibre in cattle. Livestock Science 185: 97-105.

Reed, J.D. 1995. Nutritional toxicology of tannins and related polyphenols in forage legumes. J. Anim. Sci. 73:1516-1528.

Reeves, J.B., T.H. Blosser, A.T. Baldé, B.P. Glenn, and J. Vandersall. 1991. Near infrared spectroscopy analysis of forage samples digested in situ (nylon bag). Journal of Dairy Science 74: 2664 2673.

Rezaei, J., Y. Rouzbehan, M. Zahedifar, and H. Fazaeli. 2015. Effects of dietary substitution of maize silage by amaranth silage on feed intake, digestibility, microbial nitrogen, blood parameters, milk production and nitrogen retention in lactating Holstein cows. Animal Feed Science and Technology 202: 32-41.

Riasi, A., M.D. Mesgaran, M.D. Stern, and M.J. Ruiz. 2008. Chemical composition, in situ ruminal degradability and post-ruminal disappearance of dry matter and crude protein from the halophytic plants Kochia scoparia, Atriplex dimorphostegia, Suaeda arcuata and Gamanthus gamacarpus. Animal Feed Science and Technology 141: 209-219.

Robinson, P.H., J.G. Fadel, and M. Ivan. 1996. Critical evaluation of diaminopimelic acid and ribonucleic acid as markers to estimate rumen pools and duodenal flows of bacterial and protozoal nitrogen. Can. J. Anim. Sci. 76: 587-597.

Roe, M.B., L.E. Chase, and C.J. Sniffen. 1991. Comparison of in vitro techniques to the in situ technique for estimation of ruminal degradation of protein. J. Dairy Sci. 74:1632-1640.

Russell, J.B., J.D. O'Connor, D.G. Fox, P.J. Van Soest, and C.J. Sniffen. 1992. A net carbohydrate 
and protein system for evaluating cattle diets: I. Ruminal Fermentation. J. Anim. Sci. 70:35513561.

Sarmadi, B., Y. Rouzbehan, and J. Rezaei. 2016. Influences of growth stage and nitrogen fertilizer on chemical composition, phenolics, in situ degradability and in vitro ruminal variables in amaranth forage. Animal Feed Science and Technology 215: 73-84.

Satter, L.D. 1986. Protein Supply from Undegraded Dietary Protein. Journal of Dairy Science 69: 2734-2749.

Seymour, W.M., C.E. Polan, and J.H. Herbein. 1992. In vivo Degradation of Protein in Diets Formulated for Two Degradabilities. Journal of Dairy Science 75: 2447-2453.

Shannak, S., K.H. Südekum, and A. Susenbeth. 2000. Estimating ruminal crude protein degradation with in situ and chemical fractionation procedures. Anim. Feed Sci. Tech. 85:195-214.

Sniffen, C.J., J.D. O'Connor, P.J. Van Soest, D.G. Fox, and J.B. Russell. 1992. A net carbohydrate and protein system for evaluating cattle diets: II. Carbohydrate and protein availability. J. Anim. Sci. 70:3562-3577.

Spanghero, M., C. Zanfi, M. Signor, D. Davanzo, V. Volpe, and S. Venerus. 2015. Effects of plant vegetative stage and field drying time on chemical composition and in vitro ruminal degradation of forage soybean silage. Animal Feed Science andTechnology 200: 102-106.

Stern, M.D., G.A. Varga, J.H. Clark, J. Firkins, J.T. Huber, and D.L. Palmquist. 1994. Evaluation of chemical and physical properties of feeds that affect metabolism in the rumen. J. Dairy Science. 77: 2762-2786.

Stern, M.D., A. Bach, and S. Calsamiglia. 1997. Alternative techniques for measuring nutrient digestion in ruminants. J. Anim. Sci. 75: 22562276.

Swanepoel, N., P.H. Robinson, and L.J. Erasmus. 2016. Rumen microbial protein flow and plasma amino acid concentrations in early lactation multiparity Holstein cows fed commercial rations, and some relationships with dietary nutrients. Livestock Science 190: 58-69.
Tayyab, U., M. Novoa-Garrido, M.Y. Roleda, V. Lind, and M.R. Weisbjerg. 2016. Ruminal and intestinal protein degradability of various seaweed species measured in situ in dairy cows. Animal Feed Science and Technology 213: 44-54.

Tuncer, S.D., and P. Sacakli. 2003. Rumen degradability characteristics of xylose treated canola and soybean meals. Animal Feed Science and Technology 107: 211-218.

Van Duinkerken, G., G. André, M.C.J. Smits, G.J. Monteny, and L.B.J. Sebek. 2005. Effect of rumen degradable protein balance and forage type on bulk milk urea concentration and emission of ammonia from dairy cow houses. J. Dairy Sci. 88:1099-1112.

Van Soest, P.J. 1994. Nutritional Ecology of the Ruminant. Cornell University. USA. p. 374.

Velásquez, A., and G. Pichard. 2010a. Effects of rumen fluid pre-incubation on in vitro proteolytic activity of enzymatic extracts from rumen microorganisms. Animal Feed Science and Tech. 162: 75-82.

Velásquez, A., and G. Pichard. 2010b. In vitro protein degradation by enzyme extracts of rumen origin: Comparison with methods in situ and proteases of Streptomyces griseus. Ciencia e Investigación Agraria 37: 57-70.

Wallace, R.J., C. Atasoglu, and C.J. Newbold. 1999. In: Broderick, G.A., P. Udén, M.L. Murphy, and A. Lapins (2004). Sources of variation in rates of in vitro ruminal protein degradation. J. Dairy Sci. 87:1345-1359.

Weisbjerg, M.R., T. Hvelplund, T. Hellberg, S. Olsson, and S. Sanne. 1996. Effective rumen degradability and intestinal digestibility of individual amino acids in different concentrates determined in situ. Animal Feed Science and Tech. 62: 179-188.

Xin, H., and P. Yu. 2014. Rumen degradation, intestinal and total digestion characteristics and metabolizable protein supply of carinata meal (a non-conventional feed resource) in comparison with canola meal. Animal Feed Science and Technology 191: 106-110.

Yan, T., and R.E. Agnew. 2004. Prediction of nutritive values in grass silages: II. Degradability of nitrogen and dry matter using digestibility, 
chemical composition, and fermentation data. J. Anim. Sci. 82:1380-1391.

Zagorakis, K., D. Liamadis, Ch. Milis, V. Dotas, and D. Dotas. 2015. Nutrient digestibility and in situ degradability of alternativesto soybean meal protein sources for sheep. Small Ruminant Research 124: 38-44.

Zhang, Y.L., Q. Liu, C. Wang, C.X. Pei, H.Y. Li, Y.X. Wang, W.Z. Yang, Y.S. Bai, Z.G. Shi, and X.N. Liu. 2015. Effects of supplementation of Simmental steers with2-methylbutyrate on rumen microflora, enzyme activitiesand methane production. Animal Feed Science and Technology 199: 84-92.
Zhao, Y., S. Yan, Z. He, U.Y. Anele, M.L. Swift, T.A. McAllister, and W. Yang. 2016. Effect of starch content and processing method on in situ ruminal and in vitro intestinal digestion of barley grain in beef heifers. Animal Feed Science and Technology 216: 121-128.

Zhu, W., A.H. Kingston-Smith, D. Troncoso, R.J. Merry, D.R. Davies, G. Pichard, H. Thomas, and M.K. Theodorou. 1999. Evidence of a role for plant proteases in the degradation of herbage proteins in the rumen of grazing cattle. J. Dairy Sci. 82: 2651-2658. 
